\title{
A tax to avoid the greenhouse?
}

Enthusiasm for a global tax on carbon used as fuel as a means of forfending global warming is infectiously seductive, but would probably not work and would certainly dodge the main issue in the greenhouse negotiations that lie ahead.

Just as international relations are too important to be delegated to diplomats, so it is reasonable and welcome that Britain's Royal Institute of International Affairs, otherwise known as Chatham House, should take a close interest in the prospect that the accumulation of greenhouse gases will engender global warming. A few weeks ago, for example, it published an argument by William $\mathrm{A}$. Nitze that the first stab at a greenhouse convention should include restrictions on $\mathrm{CO}_{2}$ emissions (The Greenhouse Effect: Formulating a Convention, Chatham House $£ 10.00$ ), conflicting with this journal's opinion that the most urgent need is to collect as many signatures as possible.

Today, Chatham House publishes the first of two volumes by Michael Grubb under the general title Energy Policies and the Greenhouse Effect. The first volume is subtitled Policy Appraisal (Dartmouth Publishing, $£ 25.00$ plus $£ 2.50$ postage and packing). The second, including case studies of the energy economies of several different countries, is due early next year. On the showing of the first volume, the enterprise promises an invaluable collection of data and argument. The underlying assumption is that there will be an international convention, and soon. Among other things, Grubb emphasises the importance of chlorofluorocarbons in the present pattern of greenhouse forcing 24 per cent, compared with 55 per cent for $\mathrm{CO}_{2}$ - suggesting that this is an area in which to act soon.

But then Grubb concentrates on the energy business, on the grounds that much of the rapidly growing burden of methane in the atmosphere, responsible for 15 per cent of present greenhouse forcing, derives from the extraction of coal and leakage from the oil and gas industries' installations. And he advocates a carbon tax, preferably uniform throughout the world, to discourage the relocation of industry to where carbon taxes are least. This would be his chief weapon in the reduction of greenhouse emissions, although there are careful discussions of schemes for providing people with incentives to use energy efficiently as well as of research renewable energy resources. Except on the carbon tax, Grubb is not prescriptive; his book will be all the more valuable on that account.

The seductiveness of a global carbon tax is easily understood, of course. It is a market solution, providing a single objective regulator by means of which the world's emission of $\mathrm{CO}_{2}$ could be controlled. One imagines a committee of the World Meteorological Organization and the UN Environmental Programme meeting towards the end of every year to fix the tax for the succeeding year, which each signatory would then be obliged to levy. Better still, as Grubb argues, fixing the tax rate for a decade ahead (at, say, 4 per cent above the inflation rate) could let the world's industrialists know where they stood, thus minimizing the economic disruption likely to be caused by too rapid an introduction of a carbon tax.

But the notion is unlikely to capture signatures of an international convention. The chief obstacle is the prickliness of governments about national sovereignty. It is just conceivable that a substantial proportion of those attending next February's meeting in Washington (to begin the negotiation of a greenhouse convention) will accept an obligation that $\mathrm{CO}_{2}$ emissions may have to be constrained, but hardly so that they will agree to exercise restraint by means of an externally determined tax internally administered.

Governments willing to accept restraining obligations will more probably insist that they alone should decide how best to satisfy them. Needless to say, there are also practical difficulties of collection as well as those of telling what the rate should be in fuel-rich centrally planned economies whose currencies are not convertible - China, for example, and the Soviet Union for the time being.

There is a stronger case for a carbon tax at the national level. One of the first results would be that coal, with no hydrogen worth speaking of, would be penalized relative to oil and especially to natural gas. But what would be the effects on the economy at large? Grubb's review of what economists have to say on the issue seems comprehensive, which goes to create the impression that there is much still to be understood.

Of course, a carbon tax would be a market incentive to the efficient use of fuel, but it seems that it is still not clear to what degree the oil-shocks of 1973 and 1979 , which were both inflationary (by increasing prices) and deflationary (by diverting cash from other purchases and from investment), contributed to the recessions that followed them. Grubb's case is that a national carbon tax would not be the equivalent to an externally determined price increase because the revenue it would raise could be used

\section{to offset other taxes.}

Grubb quotes the several studies that have even shown that a carbon tax might stimulate a national economy. How could it be that increasing the price of an essential commodity could have such an effect? One mechanism is that, in the hunt for fuel efficiency, people would invest in more efficient appliances, not to mention heat insulation and double glazing, all of them requiring people working in manufacturing industry. A more subtle mechanism is the means by which reduced taxes would leave many people with more to spend on commodities other than energy, or for investment, so that the gross domestic product might actually increase as the carbon tax is raised. These are tantalizing notions, which deserve more careful working through.

Where Grubb is surely on safe ground is in his protest at the continuing practice of governments of subsidizing energy, where the United States is the worst offender. (On one estimate, US energy subsidies in the form of tax rebates for oil drillers and mine operators, not to mention the activities of the US Corps of Eng nneers, amount to $\$ 40,000$ million a year.) The economists' goal of internalizing (or making explicit) the externalities (the hidden adventitious costs, that of greenhouse warming in particular) is admirable (as in the principle of "making the polluter pay"); in the context of a greenhouse convention, energy subsidies work in the other direction, and are thoroughly reprehensible. But will not the abolition of subsidies damage especially the poor and the elderly, who may not then be able to get to work or to keep warm? Grubb argues that the only rational solution is to make cash payments to those who need them. He is correct, but the case is not popular with governments.

The chief value of the economic section of this volume is that it shows how much more the economists must do. But the most serious deficiency in the greenhouse argument remains that of partitioning allowable emissions equitably between industrialized and developing countries. The eagerness of prosperous countries (Britain, for example) to offer not to increase emissions above those of some nominated previous year if others will follow suit is incompatible with avoiding global warming and allowing the development of the poor countries. And that is the nub of the argument yet to come.

John Maddox 